\title{
State Of East Indonesia (1946-1950) From Netherlands Puppet State and Return to Indonesia.
}

\author{
Anwar Firdaus Mutawally ${ }^{1}$ \\ ${ }^{1}$ Universitas Pendidikan Indonesia \\ Anwarfirdausmutawally@gmail.com
}

\begin{abstract}
This article aims to explain how the government system and the history of the administration of the State of East Indonesia from 1946-1950. The method used in this study is a historical method with data collection techniques using library research. The State of East Indonesia (NIT) was formed through two negotiations, namely the Malino Negotiation and the Denpasar Conference in 1946. The system of government of the State of East Indonesia is held by the president, prime minister, and chairman of the parliament, while regional government is led by the king. The beginning of the NIT administration was passed with instability, political turmoil, and tenuous relations with the Republic of Indonesia. However, during the reign of the prime minister Anak Agung things changed and NIT was able to improve relations with RI and help RI to gain its sovereignty. In 1949, NIT merged into the state of the Republic of the United States of Indonesia (RIS). After becoming part of the RIS state, there was a mass movement in NIT and demonstrators asked for NIT to be disbanded and reintegrated into RI. There was resistance by Chris Soumokil and Andi Azis to stop the process of integrating NIT into RI by carrying out a rebellion. However, their efforts failed and in April 1950, NIT began preparations to rejoin RI. Finally, the State of East Indonesia was officially dissolved on 17 August 1950 when President Soekarno dissolved the RIS.
\end{abstract}

Keywords: State of East Indonesia, Republic of Indonesia, Republic of Indonesia States, Integration, Federal State. 


\section{Introduction}

Japan suffered defeat in the second world war on August 14, 1945. Japan's defeat accelerated the independence of Indonesia; as a result, the Unitary State of the Republic of Indonesia was born after being proclaimed by Soekarno-Hatta on August 17, 1945. However, the Dutch colonial government that took refuge in Australia was reluctant to recognize the establishment of the state and tried to restore its power in Indonesia (Najamuddin \& Bustan, 2017, p. 390).

During the Indonesian National Revolution, the pattern of revolution in the eastern region was different from that which occurred on the islands of Java and Sumatra. Physical resistance was rare in the east and concentrated in a few places such as South Sulawesi and Bali. Taking advantage of this loophole, Lieutenant GovernorGeneral H. J. Van Mook then tried to establish a "puppet" federal state for the Dutch government in Borneo and the Great East (Groote Oost). The Greater East Region consists of Sulawesi, Bali, West Papua, the Maluku islands, and the Lesser Sundas. He offered the idea of a federated state to the Indonesian people in the Great East and received support there (Najamuddin \& Bustan, 2017, p. 390).

Van Mook's success in inviting the people of eastern Indonesia to establish a federal government later became the basis for the Malino Conference on 15-24 July 1946, which aimed to establish the State of East Indonesia. East Indonesia establishes on December 24, 1946, on Denpasar Conference (Agung, 1992, p. 38).

The State of East Indonesia is an example of a complex relationship between the government of the Republic of Indonesia, the Dutch government, and the people of East Indonesia. Although the purpose of establishing the State of East Indonesia was for the interests of the Dutch in Indonesia, the State of East Indonesia helped the Republic of Indonesia gain its sovereignty. In addition, since the ratification of the Linggarjati Agreement in March 1947. Problems have befallen the fighters of eastern Indonesia because the physical resistance of the people of eastern Indonesia was impossible. After all, Eastern Indonesia handed over to the Dutch. Therefore, the Indonesian fighters fought by entering the parliament of the State of East Indonesia until its dissolution (Djunedding, 2019, p. 570).

Based on the brief description above, the researcher wants to know how the East Indonesia State government took place in 1946-1950. The main problem raised in this research is " How did the government of the State of East Indonesia work (1946-1950)?". 


\section{Method}

This research uses historical methods or historical methods. The historical method is the process of critically examining and analyzing records of past relics, including methods for exploring, assessing, interpreting, and interpreting past facts and then analyzing and drawing conclusions from these events (Gottschalk, 1986, p. 32). According to Gray in Sjamsuddin (2012, p. 89), six stages carried out to conduct historical research, namely: 1) choosing an appropriate topic, 2) looking for all evidence (evidence) that is by the topic to be studied, 3) making what methods considered essential and appropriate to the topic when the research is in progress, 4) critically evaluate the evidence that had collected (source criticism), 5) arrange research results in a particular correct pattern and systematic, and 6) present the results in an appropriate way. that attracts attention and communicates to the reader clearly and understandably.

The collection technique used by the author in this research is library research or literature study. According to Simanjuntak and Sosrodiharjo (2014, p. 8), library research requires researchers to have a lot of "dialogue" with books, archives, documents, journals, notes, and documentation to obtain research results, which expected. The literature study is taken from field data in previous research that other people have collected. So it can be concluded that library research is a research method carried out by collecting data and information from previous research sources to obtain the expected research results.

\section{Result}

\section{The Forming Process of the State of East Indonesia (NIT)}

Since the arrival of the allied forces in Indonesia in 1945, the resistance carried out by the people of East Indonesia has been minimal, and as a result, the allied forces, namely Australia, have been able to occupy East Indonesia easily (Male, 1965, p. 4142). Lieutenant General H. J van Mook as the representative of the Dutch government and elements of NICA (Netherlands Indies Civil Administration), arrived on the island of Java on October 1, 1945 (Bayly and Harper, 2008, p. 171). He then designed a strategy for federal politics. The content of this strategy seeks to make Indonesia a Dutch state. Van Mook offered his idea to all Indonesians on February 10, 1946, but most Indonesians from Sumatra, Java, and Madura rejected Indonesia's entry as a Dutch state (Najamuddin and Bustan, 2017, p. 390).

Because of this failure, van Mook planned another strategy: establishing autonomous regions or puppet states made by the Dutch in Indonesia. This thing needs to be done by the Netherlands because by establishing an autonomous region; the Dutch government can restore its tools of power such as KNIL (Koninklijke Nederlands Indische Leger) and BB (Binnenlands Bestuur) in Indonesia through the intermediary of these puppet states (Susanti, 2013, p. 593).

In March 1946, Australia began to leave eastern Indonesia and ceded the territory to NICA (Male, 1965, p. 60). The arrival of NICA caused anger for some people in eastern Indonesia. This reason was the cause of one of the significant resistances, 
namely the Battle of Puputan Margarana in Bali on November 20, 1946. After all of Ciung Wanara's troops died in the battle, NICA became more flexible in controlling Indonesian territory (Wirawan, 2008, p. 55).

Amid these disturbances, Van Mook tried to promote his political strategy to the people of Eastern Indonesia. He promised that the federal state could guarantee the welfare of the people of East Indonesia. As a result, many people of Eastern Indonesia are interested in Van Mook's idea (Amir, 2010, p. 343). In addition, there are several reasons caused the people of Eastern Indonesia to choose to cooperate with Van Mook to establish a Federal-State and not to carry out significant physical resistance, such as in Java and Sumatra.

\section{Physical struggle against the Dutch will only bring misery to the people of East Indonesia}

Several prominent Indonesian independence fighters such as Nadjamuddin Daeng Malewa and Dr. Ratulangi saw that the Indonesian economy suffered greatly after the Japanese occupation. According to them, physical resistance with the Dutch would only further afflict the Indonesian people. Therefore, they felt that Van Mook's offer to establish a federation could avoid further damage in Eastern Indonesia (Harvey, 1990, p. 226).

\section{The kings of Eastern Indonesia wanted better autonomy}

The kings in South Sulawesi welcomed the federal-state system with the hope that with this system of government, they could give broader autonomy to improve the welfare of the people of their kingdom. They were worried that with a centralized republican system of government, their rights to govern the kingdom would be lost (Harvey, 1990, p. 228).

\section{Concerns about Javanese domination in Eastern Indonesian politics}

According to Harvey (1990, p. 223), although the people of Eastern Indonesia agreed with the proclamation of Indonesian independence. Some of them were suspicious of the dominance of the Javanese in Indonesian politics. The formation of a federal state is to stem the influence of the Javanese in Eastern Indonesia.

They are seeing the response of the people of East Indonesia, who are pretty enthusiastic about the formation of a federal state in East Indonesia. Van Mook then held negotiations in Malino in July 1946. In these negotiations, he invited representatives from Eastern Indonesia to plan the formation of a federal state. These negotiations caused mixed reactions; some agreed with the formation of a federal state, some were still sticking with a unitary state (unitary). The federal group sees that Indonesia consists of various ethnic groups, and this diversity which supported by a federation of states with their respective cultures. It differs from the group of unitary states who see Indonesia as having the same historical feeling, namely the former Dutch colony (Amir, 2010, p. 344).

To speed up the trial's outcome as he wished, Van Mook then influenced the negotiating participants by expressing the weakness of the unitary state. He revealed to the participants that a unitary state would only create division because a unitary 
state would only accommodate the wishes of the majority group. He then advised the participants to accept the federation system. Therefore, the federal group won the Malino negotiations (Amir, 2010, p. 344-345).

The plan to form a federal state was supported by the Linggarjati Negotiations between the Dutch government and the Indonesian government on November 12, 1946. The participants initiated the results of the decision on November 15, 1946, and strengthened the Dutch reason for establishing a federal state of Indonesia consisting of the Republic of Indonesia, Borneo, and the Great East (Amir, 2010, p. 345).

In December 1946, van Mook reassembled the representatives of East Indonesia at the Denpasar Conference to determine the name of the federal state of East Indonesia, the location of the capital and territory of the country, and the leader of the country. The results of the trial on December 24 then resulted in 3 decisions, namely the establishment of the State of East Indonesia (NIT), NIT with its capital in Makassar, and having territory covering the former Greater East region (Grote Oost) (Amir, 2010, p. 345).

There are two candidates for the NIT presidential nomination, namely Tjokorda Gde Rake Soekawati and Tadjoeddin Noor. After going through the voting results, Tjokorda Gde Rake Soekawati won the presidential election of the State of East Indonesia at that time and was elected president of NIT. Meanwhile, Tadjuddin Noor then elected as chairman of the NIT parliament. In addition to appointing the president and chairman of the NIT parliament, the session participants also chose Nadjamuddin Daeng Malewa as the prime minister of NIT (Djunedding, 2019, p. 570).

On January 13, 1947, President Soekawati and Prime Minister Nadjamuddin went to Jakarta to discuss the form of the first NIT cabinet with the Dutch government. The trial results then resulted in appointing nine ministers in the Nadjamuddin Cabinet (Amir, 2010, p. 345). However, according to Kadir (1984, p. 217), the appointment of Nadjamuddin's cabinet was not accompanied by the formation of government enforcement officers, this then became a gap for the Dutch military to fill the defense of NIT so that NIT was no doubt just a puppet state formed by the Dutch.

\section{State of East Indonesia Government System}

At the beginning of its establishment, the NIT Parliament consisted of two factions, namely the Development Faction and the Progressive Faction. The Development Faction filled by parliament members who support Tjokorda Gde Raka Soekawati as president of NIT, while the Progressive Faction was filled by supporters of Mr. Tadjuddin Noor, another candidate president of NIT. Since the victory of Tjokorda Gde Rake Soekawati as President of NIT on December 24, 1946, the Progressive Faction chose to oppose the government until the disbandment of NIT in 1950. The competition between these two factions then gave birth to a third faction called the National Faction, which mediates between the two (Djunedding, 2019, 2019). p. 570).

Towards the formation of the United States of Indonesia (RIS), the composition of the NIT parliament changed to 4 factions and one non-factional group. The majority 
of the parliamentary faction is filled with the Progressive Faction with 33 members, the National faction with 22 people, the Democratic Faction with five people, and the IEV Faction with three people. As for the non-faction members, there are five people. At this time, the Progressive Faction was led by Arnold Mononutu, the National Faction was led by Andi Massarapi, F.A.P Pitoi led the Democratic Faction, and O. Basalamah led the non-faction. Of the four NIT parliamentary factions previously described, only the Progressive and National (not overt) factions helped to fight for the Republic of Indonesia diplomatically (Djunedding, 2019, p. 571).

There are three thoughts that developed in the NIT parliament. The first is the B.B (Binnenlands Bestuur) school, this sect was followed by President Soekawati. The second school is Provincialist. Nadjamuddin Daeng Malewa follows these thoughts. The last thought was Republikeins or pro-Republik, this thought followed by Tadjuddin Noor (Ministry of Information of Indonesia, 1953, p. 132). The two previous schools cooperated with the Dutch government, while the Republikeins were noncooperative with the Dutch government.

Of these three schools of thought, according to the Indonesian Ministry of Information (1953, p. 132), the majority of the people of NIT adhere to the proRepublican sect and are still loyal to the Republic of Indonesia. The pro-Republican flow later became the key in integrating NIT into the Republic of Indonesia in 1950.

The king leads the majority of local governments in NIT. The kings were granted autonomous status by the Dutch government and governed by korte verklaring (short-term declarations) and lange Kontakten (long-term contracts). The succession of self-government leadership was carried in a hereditary manner. The government system's pattern in NIT will be explained below (Agung, 1996, p. 121).

According to Gie (1967, pp. 142-143) there are two patterns of government system in NIT, namely the Balinese principle (Best- tured-college) and the Lombok principle (Neo-landschap). The principle of Bali (Besturend-college) is a system of government in which the autonomous regions of NIT are governed by the Council of Kings and the House of Representatives. These two councils handle the formulation of regional regulations and financial budgets. This pattern is used by most of the NIT regions, namely Bali, Sumbawa, Flores, Timor, Sumba, North Sulawesi, Central Sulawesi, South Sulawesi, Sangihe-Talaud, and North Maluku.

The Lombok principle (Neo-landschap) is a system of government in which the autonomous regions of NIT are governed by the Daily Governing Body and the Lombok Council chaired by the Regional Head. This pattern was used in three regions, namely South Maluku, Minahasa and Lombok (Gie, 1967, p. 144-143).

\section{State of East Indonesia Existence as puppet state}

The first problem faced by the State of East Indonesia was the rebellion launched by the fighters of the Republic of Indonesia in South Sulawesi at the end of 1946. The Indonesian fighters were disappointed with Najuddin Daeng Malewa, who chose to cooperate with the Dutch government. Therefore, the people of South Sulawesi made 
efforts so that NICA would not create chaos in South Sulawesi (Ridwan, Melay, and Bunari, 2017, p. 6).

The Dutch government then deployed KNIL soldiers and allies from traditional leaders and local kings to quell the rebellion there to overcome this problem. However, the rebellion could not be quelled and spread throughout South Sulawesi. Therefore, Lieutenant General Van Mook and Simon Hendrik Spoor then deployed Dutch special forces, namely the Depot Speciale Troepen (DST), under the leadership of Raymond Westerling to quell the rebellion in South Sulawesi (Ridwan, Melay, and Bunari, 2017, p. 6-7). ).

From December 1946 to February 1947, Raymond Westerling and DST troops carried out massacres against the people of South Sulawesi. This plan aimed to suppress the rebellion and paralyze the Indonesian people's struggle in South Sulawesi (Ridwan, Melay, and Bunari, 2017, p. 6). Approximately 3,000 fighters and civilians from South Sulawesi were slaughtered in systematic killings (Ricklefs, 2005, p. 451).

From January to February 1947, armed contact between the Laskar Pejuang and the KNIL troops, such as the Langese Komara battle and the Kassi-Kassi battle. During this time, many warriors died, such as Emmy Saelan and Ranggong Daeng Romo. In addition, one of the Indonesian fighters, Robert Wolter Monginsidi, was captured by Dutch troops and thrown into the Hoogepad prison in Makassar (Djunedding, 2019, p. 571).

After the systematic killings completed, Westerling was later fired from the commander of DST, and the Dutch government transferred to West Java to establish a new army called APRA (Angkatan War Ratu Adil). The establishment of APRA aims to hide Westerling's guilt and avoid being tried as a war criminal because the genocide event will give a worse impression on relations between Indonesia and the Netherlands (Ridwan, Melay, and Bunari, 2017, p. 7).

The Governments of the Republic of Indonesia and the Netherlands signed the Linggarjati Agreement in March 1947, which recognized Java, Sumatra, and Madura as territories of the Republic of Indonesia. This agreement indirectly destroyed the hopes of the fighters of the Republic of Indonesia in Eastern Indonesia to carry out armed resistance against the Dutch because the territory of East Indonesia has legally handed over to the Netherlands in the agreement (Djunedding, 2019, p. 570).

On 22 April 1947, the NIT held its first session for 40 days to discuss the manifest political policy, which discussed continued cooperation with the Netherlands. The opposition from the Progressive Faction strongly opposed the policy and was openly pro-Republican. One of the Progressive faction members, Nani Wartabone, said "once to Djogja, always to Djogja, once independent, always independent," which created a commotion during the trial (Departemen Penerangan Indonesia, 1953, p. 132). The trial then heated up; Sonda Daeng Mattayang as the leader of the development faction, then filed a motion of no confidence against Mr. Tadjuddin Noor because Noor as the leader of the parliament, was not able to reduce the chaotic atmosphere of the trial. 
On 27 May 1947, Tadjuddin M. Noor and 32 of his followers from the Progressive Faction walked out of the trial (Departemen Penerangan Indonesia, 1953, p. 132).

In addition, prime minister Nadjamudin Daeng Malewa caused controversy in the NIT parliament because he expressed his support for the Dutch Military Aggression I on 22 July 1947. Nadjamuddin later became a delegate to the UN security council in August 1947 as a representative of NIT who supported the Dutch Military Aggression I. However, upon arrival, he was rejected by UN representatives and humiliated by the United States during the trial. Disappointed, he then blamed the Dutch government for not helping him during the trial. However, this complaint indirectly leaked the corruption scandal carried out by Nadjamuddin during his tenure as the prime minister of NIT (Departemen Penerangan Indonesia, 1953, pp. 133-135).

Nadjamuddin was arrested on 20 September 1947 and removed from his position as prime minister of NIT due to a corruption case. President Soekawati then inaugurated S. J Warouw as the new prime minister of NIT on 11 October 1947 with a cabinet containing 13 ministers. The inauguration of S. J Warouw began the reign of the Warouw cabinet (Departemen Penerangan Indonesia, 1953, pp. 135-136). The inauguration of Warouw's cabinet received significant criticism from members of parliament because the process of the inauguration of the cabinet did not go through the approval of all members of the faction, and Warouw's attitude, which strongly supported the Dutch Military Aggression I proved unpopular among the parliament (Departemen Penerangan Indonesia, 1953, p. 136). According to Djunedding (2019, p. 571), the Warouw Cabinet also supports the suppression of the youth independence fighters of the Republic of Indonesia in South Sulawesi by the KNIL.

Therefore, members of parliament from the Progressive Faction tried to overthrow this cabinet. This cabinet finally fell on December 9, 1947; President Soekawati then negotiated with all parliamentary factions. From the results of the trial, the president and the parliaments agreed with the inauguration of Ide Anak Agung Gde Agung as the new prime minister of NIT and demoting S. J Warouw to become the minister of health in the Anak Agung cabinet (Departemen Penerangan Indonesia, 1953, pp. 136-137). At this time, the inauguration of the idea of Anak Agung Gde Agung was to be supported by 16 ministers with six ministers with Republican leanings. During his reign, Anak Agung tried to improve relations between NIT and the Republic of Indonesia, which strained due to the treatment of the two previous prime ministers. Some of the efforts made by him were to improve relations with the Republican parties, which previously had a non-cooperative attitude towards the NIT, and to try to reconnect with the Republic of Indonesia by condemning the Dutch Military Aggression I on December 23, 1947, and supporting Indonesia in the Renville agreement with a speech on December 1, 1947. January 1948 Departemen Penerangan Indonesia, 1953, pp. 137-139).

According to Chaniago (2002, p. 236), the ideals of Anak Agung are to have an equal relationship between NIT and the Republic of Indonesia and to stop the use of physical revolution methods carried out by the fighters of the Republic of Indonesia. He suggested that the Republic of Indonesia carry out a peaceful struggle against the 
Dutch. Anak Agung's hard work of diplomacy finally materialized when the government of the Republic of Indonesia reestablished relations with NIT and recognized the State of East Indonesia as part of the United States of Indonesia (NIS) on January 22, 1948. As thanks to the government of the Republic of Indonesia, Anak Agung then sent Arnold Mononutu as the representative of NIT to Yogyakarta on a fraternity mission in February 1948 (Departemen Penerangan Indonesia, 1953, pp. 139-140).

The attitude of the East Indonesia Parliament during the reign of Anak Agung increasingly changed to what happened to the Republic of Indonesia, at this time, the NIT government sympathized with the situation was happening to the Republic of Indonesia. This good relationship was proved by the attitude of the East Indonesia parliament, which condemned the Madiun PKI Rebellion incident in September 1948, condemned the Second Dutch Military Aggression at the end of 1948, and recognized Soekarno and Hatta as the legitimate leaders of the Republic of Indonesia on January 28, 1949 (Departemen Penerangan Indonesia, 1953, p. 140). -141).

In addition, Anak Agung also initiated a meeting between the government of the Republic of Indonesia, autonomous states and regions, and the Dutch government. This meeting resulted in the BFO (Bijeenkomst voor Federale Overleg) or the Consultation of Federal States. At this time, the BFO acted as the initiator of the federal state in Indonesia. The BFO then held negotiations such as the Inter-Indonesian Conference (KAI) from July to August 1949. The conference brought together representatives from the Republic of Indonesia and the states and autonomous regions in Indonesia to prepare for the Round Table Conference (Wirawan, 2008, p. 56).

In August 1949, the Round Table Conference (KMB) was finally held in The Hague. After negotiations with the Dutch government, on December 27, 1949, the Dutch government officially recognized Indonesia's sovereignty as the United States of Indonesia (RIS) and returned most of its territory. Indonesia except for Papua. Nevertheless, Indonesia was obliged to pay a debt of 4.3 billion Gulden to the Netherlands as compensation for the damage caused by the Indonesian National Revolution. At that time, Soekarno also appointed as President of RIS and Moh. Hatta as Prime Minister and Vice President of RIS. The Dutch-made autonomous states and regions were then incorporated into the United States of Indonesia (RIS) (Ricklefs, 2005, pp. 466-467).

\section{State of East Indonesia dissolution}

On 23 January 1950, Westerling and 800 of his soldiers took over important places in Bandung and tried to infiltrate Jakarta to kill several RIS ministers. However, the attempt failed, and the soldiers were defeated; Westerling then fled Indonesia in February 1950 in disguise. Since the incident, the leaders of the Pasundan state were suspected of conspiring with Westerling. Therefore, the senior officials of the Pasundan State chose to dissolve their country and re-integrate into the Republic of 
Indonesia. These patterns were later imitated by other federal states in Indonesia (Ricklefs, 2005, p. 467).

From 5 until 7 February 1950; 2000 people gathered to attend the Polongbangkeng Conference. This conference aims to unite the vision of the NIT people to match the spirit of the proclamation of 17 August 1945. In addition, in the NIT parliamentary election on 20 February 1950, the majority of the NIT parliament was filled with cadres of pro-Republican factions (Djunedding, 2019, p. 571 ).

On March 16, 1950, 200,000 people in Makassar staged a demonstration to overthrow the government of the chairman of the Limboro parliament and demanded a motion from the RIS central government to dissolve NIT as soon as possible (Department of Information of Indonesia, 1953, p. 162). At the same time, the RIS defense minister, Sultan Hamengkubuwono IX, ordered that one APRIS battalion be placed in each RIS area. The demonstration in Makassar became the reason for APRIS to secure the city; the Worang Battalion was then deployed to secure the city of Makassar.

The arrival of APRIS is not always well received by NIT officials. Some of them who hate the arrival of APRIS are Chris Soumokil and Andi Azis. Chris Soumokil hates the arrival of APRIS. He thinks NIT must be defended as strongly as possible. He then conspired with Andi Azis, former KNIL, to stop the Worang battalion from arriving in Makassar on April 5, 1950 (Bahtiar, Ansaar, and Sritimuryati, 2019, p. 3)

Andi Azis then launched a rebellion with 1,300 former KNIL members and occupied the city of Makassar on April 5, 1950. Seeing the military movement carried out without his permission, President Soekawati then conveyed a message via telegram to the RIS central government that he had rejected Andi Azis' request to lead as many troops as possible. Four times and was not responsible for the rebellion (Bahtiar, Ansaar, and Sritimuryati, 2019, p. 11). Andi Azis' resistance ended after he surrendered to Jakarta and was imprisoned on April 13, 1950. Chris Soumokil and several NIT officials who conspired with Andi Azis fled to Ambon using Dutch warplanes (Bahtiar, Ansaar, and Sritimuryati, 2019, p. 15 -16).

On April 21, 1950, President Soekawati conveyed her message that NIT was dissolved and rejoined the Republic of Indonesia. This statement received support from all regions in NIT except South Maluku. Chris Soumokil, together with the former KNIL in South Maluku, then launched a rebellion by establishing the Republic of South Maluku at the end of April 1950 (Kahin, 1952, p. 460).

On May 3-5, 1950, President Soekawati then held a meeting with Moh. Hatta and dr. Mansur, president of the State of East Sumatra, plan integrating the NIT and the State of East Sumatra into the Republic of Indonesia (Kahin, 1952, pp. 460-461). As a result of the successful meeting, President Soekawati then appointed Ir. Putuhena is the new prime minister of NIT. The Putuhena Cabinet, also known as the "Liquidation" Cabinet, is tasked with preparing for the dissolution of the NIT (Djunedding, 2019, p. 572).

Finally, on August 17, 1945, coinciding with the fifth Indonesian independence day. President Soekarno dissolved RIS and returned the government to the Republic 
of Indonesia. Autonomous states and regions such as NIT were finally dissolved on the same date, and their former territories were re-integrated into the Republic of Indonesia (Ricklefs, 2005, p. 468).

\section{Conclusion}

Since the arrival of Lieutenant Governor General H. J. van Mook to Indonesia, he has found the right way to restore Dutch power in Indonesia, namely by establishing a federal state in Indonesia. Although his idea was rejected by most of the Indonesian people, he succeeded in inviting the people of eastern Indonesia to establish a Dutch-made federal-state either naturally or through coercion. The State of East Indonesia (NIT) was finally formed after going through two negotiations, namely the Malino Negotiations (July 15, 1946) and the Denpasar Conference (December 24, 1946). The leadership of the NIT is held by the president, prime minister, and speaker of parliament. The prime minister chairs the ministers in a cabinet. Meanwhile, the chairman of the parliament leads the parliament, which consists of various party factions. The president of NIT has the authority to change the cabinet and parliament.

As for the regional government system is given to the king or regional head with an area known as swapraja. Regional leaders were granted autonomy on condition that they obeyed the rules of the Dutch korte verklaring (short-term declaration) and lange Kontakten (long-term contract). There are two patterns of local government in NIT, namely the Bali pattern and the Lombok pattern.

In the early days of the formation of the NIT, conditions in eastern Indonesia were in a state of chaos, and several events occurred that strained relations between NIT and RI. Among them were the mass massacre by Westerling against Indonesian fighters, the chaos at the first session of the NIT, the controversy over the government of prime ministers Nadjamuddin and Warouw who supported the Dutch Military Aggression I. Relations between Indonesia and NIT improved again during the administration after the inauguration of the prime minister Ide Anak Agung Gde Agung. During his reign, Anak Agung brought NIT closer to the Republic of Indonesia and assisted Indonesia in gaining its sovereignty over the Netherlands. Anak Agung also initiated the establishment of the BFO in 1948 to fight for Indonesia as a federal state. During Anak Agung's time, Republicans or pro-Republicans were also growing in the NIT parliament.

RIS was finally established on December 27, 1949 and NIT later merged into the state of RIS. However, the Dutch-made countries proved unpopular and most of the people asked the RIS central government to reintegrate these states into the Republic of Indonesia. However, the process of disbanding NIT is not always well received. Two important figures of NIT, Andi Azis and Chris Soumokil, strongly opposed the dissolution of NIT. They carried out a rebellion to prevent NIT from rejoining the Republic of Indonesia. However, both failed to stem the spirit of Indonesian unity.

Disbanding NIT only started on April 21, 1950, with a message from President Sukawati, who wanted NIT to be dissolved. President Sukawati then inaugurated the last NIT cabinet, the Putuhana cabinet, in May 1950, which aimed to prepare for the disbandment of NIT. On August 17, 1950, the fifth anniversary of Indonesia's 
independence. President Soekarno dissolved RIS and returned the government to the Republic of Indonesia. Autonomous states and regions such as NIT were finally officially dissolved on the same date, and their former territories were reintegrated into the Republic of Indonesia.

\section{REFERENCES}

Agung, A.A.G. (1992). “Negara Kesatuan: Negara Indonesia Timur". Dalam BKSNT Ujung Pandang (editor), Seminar Sejarah Regional Indonesia Timur. Malino: BKSNT UJUNG PANDANG.

Agung, I. A. A. G. (1996). From the Formation of the State of East Indonesia towards the Establishment of the United States of Indonesia. Yayasan Obor Indonesia.

Amir, M. (2010). Dari Federalis ke Unitaris: Studi Kasus Sulawesi Selatan 19451950. Patanjala, 2(2), 341-358.

Bahtiar, B, Ansaar, \& Sritimuryati. (2019). "PERISTIWA ANDI AZIS DI SULAWESI SELATAN 5 APRIL 1950 (ANDI AZIS EVENTS IN SOUTH SULAWESI 5 APRIL 1950)". In Balai Pelestarian Nilai Budaya Provinsi Sulawesi Selatan (editor), Seminar Series in Humanities and Social Sciences. Makassar: Universitas Hasanuddin.

Bayly, C., \& Harper, T. (2008). Forgotten Wars: The End of Britain's Asian Empire. Westminster: Penguin Books.

Chaniago, J. R. (2002). Menuju Negara Kesatuan Republik Indonesia: Peranan Pemimpin Lokal dalam Dinamika Politik di Sulawesi Selatan dan Sumatera Timur 1950. (Unpublished Disertation). Yogyakarta: Universitas Gadjah Mada.

Departemen Penerangan Indonesia. (1953). Provinsi Sulawesi. Makassar: Kementrian Penerangan.

Djunedding, B. (2019). PERJUANGAN TANPA REVOLUSI: PERSPEKTIF BARU DALAM MEMAHAMI KEKERASAN PERIODE REVOLUSI DI INDONESIA TIMUR 19451950. Al-Qalam, 25(3), 561-574.

Gie, T. L. (1967). Pertumbuhan Pemerintahan Daerah di Negara RI. Jakarta: Gunung Agung.

Gottschalk, L. (1986). Mengerti Sejarah. Jakarta: Yayasan Penerbit Universitas Indonesia.

Harvey, B. (1990). Sulawesi Selatan: Boneka dan Patriot. Dalam Kahin, A. R. (editor), Pergolakan Daerah Pada Awal Kemerdekaan (hlm. 212 -240). Jakarta: Grafiti.

Kadir, H. (1984). Sejarah Perjuangan Kemerdekaan Indonesia di Sulawesi Selatan. Ujung Pandang: BAPPEDA Tingkat UNHAS. 
Kahin, G. M. (1952). Nationalism and revolution in Indonesia. Ithaca: Cornell University Press.

Makkelo, I. D. (2017). PENATAAN KOTA DAN MASYARAKAT PERKOTAAN: MAKASSAR SEBAGAI IBUKOTA NEGARA INDONESIA TIMUR (NIT) 19461950. SASDAYA: Gadjah Mada Journal of Humanities, 2(1), 315-333.

Male, B. (1965). Australia and the Indonesian Nationalist Movement 1942-1945. (Unpublished Thesis). Canberra: Australian National University.

Najamuddin, N., \& Bustan, B. (2017). “Terbentuknya Negara Indonesia Timur (NIT) Di Sulawesi Selatan 1946-1950". In Najamuddin (editor), Seminar Nasional LP2M UNM (hlm. 390-395). Makassar: Universitas Negeri Makassar.

Ricklefs, M. C. (2005). Sejarah Indonesia Modern, 1200-2004. Jakarta: Penerbit Serambi.

Simanjuntak, B. A. \& Sosrodiharjo, S. (2014). Metode Penelitian Sosial (Edisi Revisi). Yayasan Pustaka Obor Indonesia.

Sjamsuddin, H. (2012). Metodologi Sejarah. Yogyakarta: Ombak.

Susanti, A. F. (2013). NEGARA INDONESIA TIMUR TAHUN 1946-1950. Avatara, 1(3), 592-596.

Wirawan, A. B. (2008). Respons Lokal Terhadap Revolusi Indonesia Di Sunda Kecil, 1945-1950. Humaniora, 20(1), 51-62.

Yusuf, Z. R, Melay, R., \& Bunari. (2017). Pembantaian Raymond Pierre Paul Westerling Di Sulawesi Selatan Sebagai Upaya Belanda Mendirikan Negara Indonesia Timur (1946-1947). Jurnal Online Mahasiswa Fakultas Keguruan dan Ilmu Pendidikan Universitas Riau, 4(1), 1-10. 